\title{
Pemahaman Generasi Millenial Terhadap Hak Asasi Manusia: Studi Hak Asasi Manusia Menurut Alkitab
}

\author{
Herowati Sitorus \\ Prodi Pendidikan Agama Kristen, Institut Agama Kristen Negeri Tarutung
}

\begin{abstract}
Abstrak
Penelitian ini mengangkat judul: Pemahaman Generasi Millenial Terhadap Hak Asasi Manusia: Studi Hak Asasi Manusia Menurut Alkitab. Masyarakat millenial kurang pengakuan akan keberadaan manusia terhadap manusia lainnya. Terjadi pelanggaran HAM di berbagai sektor kehidupan. Dasar-dasar HAM adalah dari akar keagamaan. Manusia adalah gambar Allah atau dalam bahasa Paulus, human is divine original. Alkitab memberikan tempat yang sangat tinggi bagi martabat manusia yang berisikan pemahaman yang mencerminkan penghargaan terhadap hak dan kebebasan hidup manusia. Penulisan jurnal ini menggunakan metode penelitian kualitatif, yaitu penelitian yang bersumber dari buku-buku teks, jurnal dan bahan-bahan tertulis lainnya. Temuan penelitian adalah berkembangnya teknologi juga menciptakan cara baru bagi pelanggaran HAM. Dalam menangani kasus di atas pemerintah mengeluarkan Undang-Undang No. 11/2008 tentang Informasi dan transaksi Elektronik (ITE) yang mengatur tentang HAM karena UU yang telah ada dirasa belum cukup dalam menangani kasus HAM di era millenial ini.
\end{abstract}

Katakunci : generasi milenial, Hak Azasi Manusia

\begin{abstract}
This research raises the title: Understanding of Millennial Generation about Human Rights: The Study of Human Rights According to the Bible. Millennial society lacks acknowledge the existences of humans to other humans. Human rights violations occurred in various sectors of life. The basics of human rights are from religious roots. Humans are images of God or in the language of Paul, the original human is divine. The Bible places a very high place on human dignity which contains an understanding that reflects an appreciation of the rights and freedoms of human life. Writing this journal uses qualitative research methods, namely research sourced from text books, journals and other written materials. The research finding is that the development of technology also creates new ways for human rights violations. In handling the above case the government issued Law No. 11/2008 regarding Electronic Information and Transactions (ITE) which regulates human rights because existing laws are deemed insufficient in handling human rights cases in this millennial era.
\end{abstract}

Keywords: millennial generation, human rights

93 | Korespondensi mengenai artikel dapat dilakukan kepada: Herowati Sitorus, Institut Agama Kristen Negeri Tarutung, Jl. Raya Tarutung-Siborong KM 11, Silangkitang, Sipoholon, Tapanuli Utara (22452), Indonesia e-mail Corresponding: sitorusherowati@yahoo.co.id 


\section{PENDAHULUAN}

Sosial media memiliki beberapa bahkan banyak kegunaan, namun yang paling penting, sosial media memiliki fungsi untuk menghubungkan seseorang dari daerah yang lain (daerah yang jauh) dengan daerah yang satunya. Intinya berguna sebagai 'alat' komunikasi.

Masuk pada era atau zaman millenial di mana semua kebutuhan manusia tidak luput dari teknologi, teknologi hidup bersama manusia bahkan teknologi menguasai manusia. Banyak manfaat yang diberikan kepada kita khususnya dalam memenuhi segala kebutuhan kita. Terlebih lagi berkat teknologi saat ini ada yang namanya "Sosial Media" atau "Dunia Maya", yaitu cara berkomunikasi secara tidak langsung dengan orang lain yang menggunakan Gadget sebagai medianya. Terdapat beberapa aplikasi media sosial seperti Instagram, Facebook, Twitter dan Path. Saat ini semua usia dan kalangan pasti mempunyai beberapa akun sosial media. Millennial generation atau generasi Y juga akrab disebut generation me atau echo boomers. Secara harfiah memang tidak ada demografi khusus dalam menentukan kelompok generasi yang satu ini. Namun, para pakar menggolongkannya berdasarkan tahun awal dan akhir. Penggolongan generasi Y terbentuk bagi mereka yang lahir pada 1980 - 1990, atau pada awal 2000, dan seterusnya. Awal 2016 Ericsson mengeluarkan 10 Tren Consumer Lab untuk memprediksi beragam keinginan konsumen .

\section{METODE PENELITIAN}

Dalam upaya membahas suatu masalah dalam penelitian, diperlukan suatu metode penulisan agar memperoleh jawaban dan paradigma baru atas permasalahan yang dibahas. Penulisan jurnal ini menggunakan metode penelitian kualitatif, yaitu penelitian yang bersumber dari buku-buku teks, jurnal dan bahan-bahan tertulis lainnya. Penelitian ini berdasarkan pada penelitian studi kepustakaan (library research).

\section{HASIL PEMBAHASAN}

Dasar negara kita Pancasila mengandung pemikiran bahwa manusia diciptakan oleh Tuhan yang Maha Esa mengandung dua aspek, yaitu aspek individualis (pribadi) dan aspek sosialis (bermasyarakat). Maka dari itu kebebasan setiap individu dibatasi oleh hak asasi individu lainnya. Negara dan pemerintah bertanggung jawab untuk menghormati, melindungi, membela, dan menjamin hak asasi manusia.

Kasus-kasus pelanggaran HAM pada zaman millenial yang sering terjadi adalah pelecehan atau pengucilan suatu ras dan agama yang menyebabkan permasalahan-permasalahan. Jika hal tersebut dibiarkan pastinya merugikan suatu pihak baik secara individu atau kelompok bahkan mengakibatkan hilangnya nyawa seseorang. Namun sayangnya saat ini, banyak kalangan (terutama 
remaja) yang salah mempergunakan fungsi dari media sosial tersebut. Secara tidak sadar mereka mencemari nama baiknya bahkan orang lain atau menjelek-jelekan nama orang lain dan timbulah pelanggaran HAM yaitu pembulian dll.

Berikut jenis pelanggaran HAM di media sosial.

a. Pencemaran Nama Baik

b. Penipuan Online

c. Bullying

d. Dampak yang tidak kalah merugikan bagi si korban dari pelanggaran HAM

Hak asasi manusia adalah hak-hak yang dimiliki manusia bukan karena diberikan oleh satu pihak (negara, penguasa, masyarakat) tetapi berdasarkan martabatnya sebagai manusia. Manusia memilikinya karena ia adalah manusia dan hak itu tidak dapat dihilangkan atau dinyatakan tidak berlaku oleh orang lain atau negara sekalipun. Hak-hak ini hanya perlu diakui keberadaannya sebagai suatu yang esensial dan melekat dalam diri manusia itu sendiri. Jika tidak ada pengakuan terhadap HAM maka tidak ada juga pengakuan akan martabat manusia itu sendiri.

Namun realitas saat ini dalam masyarakat millenial kurang pengakuan akan keberadaan manusia terhadap manusia lainnya. Terjadi pelanggaran HAM di berbagai sektor kehidupan mulai dari keluarga, sekolah, institusi, gereja bahkan lingkungan kerja. Sebagai contoh; kebebasan berbicara (mengeluarkan pendapat) sering terjadi. Di lingkungan keluarga acap kali anak-anak bahkan istri dibatasi mengeluarkan pendapat dan idenya. Kadangkala pendapat atau ide yang disampaikan tidak direspon dan langsung ditolak.

Di tengah masyarakat, hak mengeluarkan pendapat bagi kaum wanita juga terbatas. Dalam acara adat bahkan wanita tidak memiliki ruang untuk mengeluarkan pendapat/berbicara. Kaum muda juga hanya memiliki ruang yang sangat sempit bahkan hampir tidak ada ruang untuk mengeluarkan pendapat. Di lingkungan kerja, bawahan tidak bebsa berpendapat.

Terjadi perampasan akan hak orang lain demi memenuhi kepuasan diri sendiri. Jika tidak ada pengakuan terhadap HAM maka tidak ada juga pengakuan akan martabat manusia itu sendiri. Dasar dari HAM adalah bahwa manusia berhak mendapatkan kesempatan untuk hidup dan berkembang sesuai dengan bakat dan cita-citanya. Dalam zaman milineal penggunaan media sosial dalam berkomunukasi seperti facebook, twitter, instagram dapat dipakai untuk mencemarkan nama baik orang lain, sehingga terjadi pembulian. Pencemaran nama baik, termasuk pelanggaran HAM berat.

Ada 3 hak asasi manusia yang paling fundamental (pokok), yaitu : Hak Hidup (life), Hak Kebebasan (liberty), Hak Memiliki (property). Dalam perjalanan kehidupan manusia, hak asasi manusia digolongkan menjadi beberapa macam, yaitu: hak asasi pribadi, hak asasi politik, hak asasi hukum, hak asasi ekonomi, hak asasi peradilan, dan hak asasi sosial budaya. Demi menegakkan hak asasi manusia yang dimiliki oleh warga negara Indonesia, pemerintah perlu melakukan 
JURNAL CHRISTIAN HUMANIORA

Vol.4, No.1, May 2020, pp. 93-103

p-ISSN: 2598-6317- e-ISSN: 2599-196

beberapa upaya guna menjaga dan melindungi hak asasi warga negaranya sebagai salah satu bentuk penerapan tujuan pemerintah yang berdaulat ke dalam dan keluar.

Hak asasi manusia tidak pernah boleh dilepaskan dari kewajiban asasi manusia. Hak mengimplementasikan kewajiban, sebab hak hanya menjadi hak setelah kewajiban terpenuhi. Sebaliknya kewajiban juga mengimplementasikan hak, sebab kewajiban dapat dilaksanakan dengan sebaik-baiknya jika haknya sebagai manusia bermartabat dihargai dan dihormati.

Eka Darma Putra mengatakan bahwa hak tanpa kewajiban adalah kesewenang-wenangan, sedangkan kewajiban tanpa hak adalah perbudakan. Bagi orang Kristen pelaksanaan HAM berarti pelaksanaan hak-hak sekaligus kewajiban-kewajiban paling asasi yang diletakkan oleh Sang Maha Pencipta pada setiap manusia. Hak asasi manusia terkait amat erat dengan hakikat manusia sebagaimana dikehendaki oleh Allah pada waktu penciptan manusia. Artinya tanpa hak-hak dan kewajiban asasi ia bukanlah manusia seperti yang dikehendaki oleh Allah pencipta. apabila pemahaman kita tentang HAM bersumber pada kedaulatan Allah atas manusia, maka implikasinya adalah bahwa tidak ada satu orangpun atau satu lembagapun, termasuk negara berwenang untuk mengurangi atau membatalkan hak-hak dan kewajiban asasi manusia, tanpa berhadapan dengan Allah sendiri.

\section{Hak Asasi Manusia Menurut Alkitab}

\section{Perjanjian Lama}

Dasar-dasar HAM adalah dari akar keagamaan. Manusia adalah gambar Allah atau dalam bahasa Paulus, human is divine original. Alkitab memberikan tempat yang sangat tinggi bagi martabat manusia, sehingga secara eksplisit ada perintah-perintah untuk menghormati martabat manusia. Alkitab berisikan pemahaman yang mencerminkan penghargan terhadap hak dan kebebasan hidup manusia. Christopher mengatakan bahwa Alkitab merupakan sebuah proklamasi dasar tentang HAM yang jelas terlihat dalam segenap Hukum Taurat Musa. Berdasarkan Kejadian 1:26, kata berkuasa (weyirdu = to break, tread) memiliki padanan kata dengan kebebasan untuk mengatur dan menguasai. Manusia diberikan kewenangan untuk mengatur dan menguasai ciptaan lainnya, baik dalam memberi nama maupun memanfaatkannya demi keberlanjutan hidupnya. Kebebasan untuk mengatur dan menguasai ini semestinya dilaksanakan dalam relasi tanggung jawab terhadap Allah. Ketika manusia menjalankan mandat Allah itu, tidak menjadi serakah dan bertindak sewenang-wenang.

Hak asasi manusia bersumber pada pernyataan Allah terhadap manusia, pada tindakan Allah dalam sejarah manusia. HAM bukanlah rumusan ideal manusia tentang dirinya sendiri melainkan pemahaman tentang apa yang dikehendaki Allah mengenai manusia, siapa manusia, apa eksistensinya dan apa tujuan hidupnya dari perspektif Allah. 
Hak-hak asasi ini terkait amat erat dengan hakikatnya sebagai manusia sebagaimana yang dikehendaki oleh Allah pada waktu Ia menciptakan manusia. Setiap kali kita berbicara tentang manusia hendaknya memakai sikap yang sangat hormat dan tidak sembarangan. Karena nilai manusia begitu tinggi, jauh lebih tinggi dari segala ciptaan yang Tuhan letakkan di bawahnya. Kita perlu menerobos batasan sejarah dan limitasi waktu untuk melihat nilai yang Allah berikan kepada kita di dalam kekekalan, memahami potensi yang ada di dalam kita, lalu mengasihinya, mendidiknya bahkan menguasainya.

Namun dalam pelaksanaan tugas/mandat yang diberikan Allah (hak) manusia cenderung memperlihatkan nafsunya untuk berkuasa. Manusia tidak segan-segan untuk merampas hak hidup orang lain. Bahkan Alkitab juga menceritakan bagaimana Kain membunuh Habel, Kain melanggar HAM Habel, yaitu hak untuk hidup. Kisah ini dianggap sebagai bentuk awal kisah pelanggaran HAM. Setelah Kain membunuh Habel, "Allah bertanya kepadanya: Apa yang telah kau perbuat ini?" (Kejadian 4:10), merupakan suatu pertanyaan yang memiliki nilai koherensi dengan norma kehidupan yang dimiliki manusia yang perlu dihargai. Pertanyaan yang diajukan Allah kepada Kain, menurut JB. Banawiratma menegaskan HAM, tetapi juga kewajiban asasi manuisa, yakni kewajiban Kain untuk menjaga Habel, saudaranya.

Sekalipun isi Alkitab banyak bermuatan menjungjung tinggi HAM, namun dalam Alkitab juda dapat kita temukan nas-nas ataupun kisah-kisah yang berisikan pelanggaran HAM. Sebagai contoh: Keluaran 22:18-20, di dalam ayat ini ada peraturan tidak diperbolehkannya seorang ahli sihir perempuan tetap hidup (perampasan hak hidup seseorang). Ada juga ajakan untuk menumpas seseorang yang mempersembahkan korban kepada allah kecuali kepada TUHAN. Perempuanperempuan dalam Alkitab juga digambarkan sebagai orang yang sering menerima perlakuan yang bertentangan dengan HAM, seperti: Hagar, dia adalah hamba di bawah kekuasaan Sarai, ada pengakuan dari Abraham kepada Sarai untuk berbuat apa yang dipandangnya baik kepada Hagar. Sarai menindas Hagar, sehingga ia lari meninggalkannya (Kejadian 16:1-16; Kejadian 21:9-21). Ada Tamar yang telah diperkosa Amnon, setelah dia memperkosa Tamar lalu Tamar diusir dan dikurung (2 Samuel 13:1-22), anak perempuan Yefta, demi nazarnya ia mempersembahkan anak perempuannya (Hakim-hakim 11:29-40).

Kejadian 9:6; mencatat pernyataan yang Allah ucapkan setelah Nuh keluar dari bahtera: "Siapa yang menumpahkan darah manusia, darahnya akan tertumpah oleh manusia, sebab Allah membuat manusia itu menurut gambar-Nya sendiri". Allah tidak mengizinkan perampasan hak hidup orang lain. Memang ayat ini tidak memberitahukan kepada kita berapa besar nilai manusia, namun ayat ini menyodorkan satu penilaian yang amat penting bahwa manusia sama dengan manusia lainnya. Sehingga manusia tidak bisa seenaknya berkata, saya telah membunuh seseorang, saya akan menggantinya dengan lima ribu dollar. Karena nilai manusia tidak identik dengan lima 
JURNAL CHRISTIAN HUMANIORA

Vol.4, No.1, May 2020, pp. 93-103

p-ISSN: 2598-6317- e-ISSN: 2599-196

ribu dollar. Kalau kau membunuh satu orang, kau menumpahkan darahnya, darahmupun akan ditumpahkan oleh manusia. "Siapa yang menumpahkan darah manusia, darahnya akan tertumpah oleh manusia, sebab Allah membuat manusia itu menurut gambar-Nya sendiri” (Kejadian 9:6). Ayat ini tidak mengatakan orang pandai boleh menumpahkan darah orang pandai, orang bodoh boleh menumpahkan darah orang bodoh.

Manusia mempunyai hak hidup. Dari mana kita mengetahui hal itu? Baik kita hidup, kita bergerak, kita ada, semua itu bergantung pada Tuhan. Allah memberi hidup kepada manusia bukan untuk dipermainkan dan dihujat semaunya. Allah memberikan hak hidup kepada manusia adalah supaya manusia menikmatinya. Sebab itu, bila terjadi salah membunuh atas keputusan hukum yang tidak adil, Allah menyediakan kota perlindungan bagi bangsa Israel, membuktikan hak hidup adalah sesuatu yang dihargai Tuhan. "Dan haruslah rapat umat membebaskan pembunuh dari tangan penuntut darah, dan haruslah rapat umat mengembalikan dia ke kota perlindungan, ke tempat ia telah melarikan diri; di situlah ia harus tinggal sampai matinya imam besar yang telah diurapi dengan minyakyang kudus" (Bil. 35:25). Ketika orang lain memfitnahmu, Allah berfirman, jangan hanya berdasarkan satu orang saksi saja; agar jangan sampai kamu salah dibunuh. Diperlukan banyak saksi adalah bukti Allah menghargai hak hidupmu.

Dengan demikian, hak manusia disatukan dengan hidupnya, badan hukum manapun tidak boleh memperlakukan seseorang dengan sembarangan, tidak boleh merampas hak hidup seseorang dengan seenaknya, karena Allah sendiri menghargai hak itu. Lamekh bercerita kepada kedua istrinya, yaitu Ada dan Zila, bahwa ia telah membunuh seorang laki-laki karena ia melukainya, membunuh seorang muda karena ia memukul Lamekh sampai bengkak (Kejadian 4:23). Lamekh telah merampas hak hidup orang lain dengan main hakim sendiri. Dia telah melampaui otoritas Allah, bahwa hanya Allah yang berhak atas hidup manusia. Jangan membunuh (Keluaran 20:13; Ulangan 5:17). Siapa yang menumpahkan darah manusia, darahnya akan tertumpah oleh manusia.

Pernyataan ini begitu tegas, begitu mutlak di mana Allah menghargai hidup manusia, tidak menginginkan manusia menumpahkan darah sesamanya. Istilah-istilah yang biasa dipakai dalam Perjanjian Lama untuk membunuh ialah harag, hemit, rasah (membunuh dengan sengaja) yang bertujuan untuk mencegah atau membasmi hak pembalasan dendam.

Manusia mempunyai hak beragama. Manusia mempunyai hak untuk beribadah kepada Allah. Jadi, jelaslah sudah bahwa Allah memberi manusia insting untuk mengadakan komunikasi dua arah. Insting ini lahir dari sifat relasi antara manusia dengan Allah; the relation between men and God is the relational nature of communication. Itu sebabnya Allah menyediakan hari Sabat, agar manusia boleh menikmati perhentian yang Allah berikan kepadanya dan bersekutu dengan Allah. Ketika hak bangsa Israel untuk beribadah ini diganggu, "Allah berfirman kepada Musa, pergilah menghadap Firaun, katakanlah kepadanya, biarkanlah umat-Ku pergi untuk melayani Tuhan; menyembah Allah" (Keluaran 5:1; 7:16; 8:1, 20; 9:1, 13; 10:3-4). 
Manusia mempunyai hak bekerja, mengembangkan bakat yang ada lahir dari sifat ciptaan. Bakat apapun yang ada pada manusia, berhak untuk dikembangkan. Itulah sebabnya mengapa manusia bebas memilih pekerjaan yang sesuai dengan bakat yang diterima dari Tuhan. Itulah kebebasan bekerja. Manusia akan makan dari hasil jerih lelahnya, pekerjaan lancar dan dapat makan dari hasil jerih lelahnya (Mazmur 128:2). Manusia mempunyai hak untuk bekerja dan menikmati hasil kerjanya.

Manusia mempunyai hak untuk menikah dan membina rumah tangga. Menikmati kesenangan dalam berumahtangga, menghargai pernikahan adalah ajaran yang begitu jelas, sebab itu, "setiap orang harus menghargai pernikahan" adalah satu perkara yang penting di dalam hak asasi manusia. Hendaknya setiap orang menghargai pernikahan. Menurut Alex Sobur manusia mempunyai hak untuk memilih pasangan hidup, setelah menjalin hubungan kasih barulah membina rumah tangga yang dianggap ideal, itu adalah hak manusia. Alkitab mengajarkan dengan jelas, pasangan yang telah disatukan oleh Tuhan tidak dapat dipisahkan oleh manusia. Allah menciptakan pria seturut gambar-Nya, Allah juga menciptakan wanita seturut gambar-Nya. Ketika pernikahan dihargai, rumah tangga menjadi satu unit yang tetap. Jadi, sebuah pernikahan, baik pernikahan antara orang percaya atau antara orang tidak percaya, setiap orang harus menghargainya. Manusia mempunyai hak untuk menikmati pernikahannya.

Manusia mempunyai hak untuk menikmati harta pribadinya. Di dalam sepuluh hukum disebutkan, jangan menginginkan harta orang lain. Jangan mencuri. Kita tahu bahwa Allah menghargai manusia dan memberinya hak untuk menikmati harta pribadi. Meskipun Alkitab juga mengajarkan banyak hal tentang memperoleh harta dengan cara yang halal, namun Alkitab juga mengajarkan, setelah seseorang memperoleh harta pribadi, Allah tidak menghendaki orang lain menggunakan pelbagai alasan untuk perampas dan mengeksploitasinya dengan semena-mena.

\section{Perjanjian Baru}

Kisah-kisah Injil menampilkan Yesus sebagai wujud solidaritas Allah terhadap kaum lemah dan tertindas. Misi Yesus adalah misi yang berhubungan dengan Kerajaan Allah berupa pemberitaan dan pemberlakuan kabar baik bagi orang tertindas, orang lemah dan mereka yang diperlakukan secara tidak manusiawi. "Roh Tuhan ada pada-Ku, oleh sebab Ia telah mengurapi Aku, untuk menyampaikan kabar baik kepada orang-orang miskin; dan Ia telah mengutus Aku untuk memberitakan pembebasan kepada orang-orang tawanan, dan penglihatan bagi orangorang buta, untuk membebaskan orang-orang yang tertindas, untuk memberitakan tahun rahmat Tuhan telah datang” (Luk. 4:18-19).

Yesus tampil sebagai pembela HAM. Namun justru karena hal inilah, Ia dibenci dan dimusuhi. Yesus diadili dan akhirnya dihukum mati di kayu salib. Yesus, sosok pembela HAM telah menjadi 
JURNAL CHRISTIAN HUMANIORA

Vol.4, No.1, May 2020, pp. 93-103

p-ISSN: 2598-6317- e-ISSN: 2599-196

korban pelanggaran HAM. Pelanggrana HAM terhadap Yesus dilakukan oleh pemerintah yang berkuasa.

Yesus juga menyatakan keberpihakannya akan hidup manusia. Ada perintah yang dengan tegas dikatakan Yesus, jangan membunuh (Mat. 5:21-26). Yesus memerintahkan manusia untuk menghormati hidup manusia. Abineno mengatakan bahwa hidup manusia penting dan berharga karena pentingnya hidup manusia maka ia harus dilindungi oleh rupa-rupa peraturan (bdn. Kel. 19:2-23; Bil. 35:10-34; Ul. 19:1-13; Yos. 20:1-9). Yesus telah membersihkan agama Yahudi dari aspek-aspeknya yang legalistis dan dengan ini mulailah kerygma Perjanjian Baru sebagai kuasa yang membebaskan. Yoh. 12:17: “Orang banyak yang bersama-sama dengan Dia ketika Ia memanggil Lazarus keluar dari kubur dan membangkitkannya dari antara orang mati, memberi kesaksian tentang Dia”. Yesus berusaha mengembalikan hak hidup sejumlah orang yang hak hidupnya diambil oleh maut.

Yesus juga meminta pendapat murid-murid-Nya. Ada hak para murid untuk menyampaikan pendapatnya. Mat. 22:42: "Apakah pendapatmu tentang Mesias? Anak siapakah Dia?" Kata mereka kepada-Nya: "Anak Daud." Mat. 26:66; "Bagaimana pendapat kamu?" Mereka menjawab dan berkata: "Ia harus dihukum mati!" Dalam pengajaran-Nya, Yesus tidak pernah bersikap otoriter, tetapi ada nilai-nilai demokrasi yang Ia tampilkan. Hal ini menunjukkan bahwa Yesus juga menghargai kebebasan orang lain untuk menyampaikan pendapatnya.

\section{Pemahaman Generasi Mellenial}

Karakteristik Millenial berbeda-beda berdasarkan wilayah dan kondisi sosial-ekonomi. Namun, generasi ini umumnya ditandai oleh peningkatan penggunaan dan keakraban dengan komunikasi, media, dan teknologi digital. Di sebagian besar belahan dunia, pengaruh mereka ditandai dengan peningkatan liberalisasi politik dan ekonomi; meskipun pengaruhnya masih diperdebatkan. Masa Resesi Besar (The Great Recession) memiliki dampak yang besar pada generasi ini yang mengakibatkan tingkat pengangguran yang tinggi di kalangan anak muda, dan menimbulkan spekulasi tentang kemungkinan krisis sosial-ekonomi jangka panjang yang merusak generasi ini.

Generasi millenial lebih gampang memahami apa itu HAM dari berbagai media sosial yang memberikan informasi tentang HAM. Namun generasi millenial cenderung terlalu bebas mengekspresikan pemahamannya serta menyebarkan informasi dengan cepat. Tanpa mereka sadari mereka menjadi pelaku pelanggran HAM seperti yang dijelaskan di atas. Secara teori pemahaman HAM mereka dapatkan, secara prakti mereka sulit melakukannya.

\section{Studi HAM Pada Era Millenail menurut Pemahaman Alkitab}

100 | Pemahaman Generasi Millenial Terhadap Hak Asasi Manusia..., Herowati Sitorus Jurnal Christian Humanioran | http://e-journal.iakntarutung.ac.id/index.php/humaniora 
Hak asasi manusia (HAM) merupakan nilai dan norma yang sangat penting bagi kehidupan manusia di dunia ini. Dengan adanya perlindungan dan penegakan HAM, maka kehidupan manusia yang beradab dan sejahtera dapat diwujudkan. Manusia adalah mahkluk ciptaan Tuhan yang paling mulia, dan mempunyai derajat yang luhur sebagai manusia, mempunyai budi dan karsa yang merdeka sendiri.

Jadi HAM pada hakekatnya merupakan hak-hak fundamental yang melekat pada kodrat manusia sendiri, yaitu hak-hak yang paling dasar dari aspek-aspek kodrat manusia sebagai manusia. Setiap manusia adalah ciptaan yang luhur dari Tuhan Yang Maha Esa. Setiap manusia harus dapat mengembangkan dirinya sedemikian rupa sehingga ia harus berkembang secara leluasa. Pengembangan diri sebagai manusia dipertanggung-jawabkan kepada Tuhan sebagai asal dan tujuan hidup manusia.

Semua hak yang berakar dalam kodratnya sebagai manusia manusia adalah hak-hak yang lahir bersama dengan keberadaan manusia itu sendiri. Dengan demikian hak-hak ini adalah universal atau berlaku di manapun di dunia ini. Di mana ada manusia di situ ada HAM dan harus dijunjung tinggi oleh siapapun tanpa kecuali. HAM tidak tergantung dari pengakuan orang lain, tidak tergantung dari pengakuan mesyarakat atau negara.

Manusia memperoleh hak-hak asasi itu langsung dari Tuhan sendiri karena kodratnya (secundum suam naturam). Penindasan terhadap HAM bertentangan dengan keadilan dan kemanusiaan, sebab prinsip dasar keadilan dan kemanusiaan adalah bahwa semua manusia memiliki martabat yang sama dengan hak-hak dan kewajibankewajiban yang sama. Oleh karenanya, setiap manusia dan setiap negara di dunia wajib mengakui dan menjunjung tinggi hak asasi manusia (HAM) tanpa kecuali. Penindasan terhadap HAM berarti pelanggaran terhadap HAM.

Setiap manusia, setiap negara di manapun, kapanpun wajib mengakui dan menjunjung tinggi HAM sebagai hak-hak fundamental atau hak-hak dasar. Penindasan terhadap HAM adalah bertentangan dengan keadilan dan kemanusiaan. Hak alamiah itu meliputi hak atas hidup, hak kemerdekaan, hak milik dan hak kebahagiaan. Pemikiran John Locke ini dikenal sebagai konsep HAM yang sangat berpengaruh terhadap perkembangan HAM di berbagai belahan dunia.

Akhir-akhir ini di dunia Internasional maupun di Indonesia, dihadapkan banyak pelanggaran hak asasi manusia dalam wujud teror. Leiden \& Schmit, mengartikan teror sebagai tindakan berasal dari suatu kekecewaan atau keputusasaan, biasanya disertai dengan ancaman- ancaman tak berkemanusiaan dan tak mengenal belas kasihan terhadap kehidupan dan barang-barang dilakukan dengan cara-cara melanggar hukum.

Teror dapat dalam bentuk pembunuhan, penculikan, sabotase, subversiv, penyebaran desasdesus, pelanggaran peraturan hukum, main hakim sendiri, pembajakan dan penyanderaan. Teror 
JURNAL CHRISTIAN HUMANIORA

Vol.4, No.1, May 2020, pp. 93-103

p-ISSN: 2598-6317- e-ISSN: 2599-196

dapat dilakukan oleh pemerintah mapun oleh masyarakat (oposan). Teror sebagai bentuk pelanggaran hak asasi manusia yang kejam (berat), karena menimbulkan ketakutan sehingga rasa aman sebagai hak setiap orang tidak lagi dapat dirasakan. Dalam kondisi ketakutan maka seseorang/masyarakat sulit untuk melakukan hak atau kebebasan yang lain, sehingga akan menimbulkan kesulitan dalam upaya mengembangkan kehidupan yang lebih maju dan bermartabat.

Upaya perlindungan HAM penekanannya pada berbagai tindakan pencegahan terhadap terjadinya pelanggaran HAM. Perlindungan HAM terutama melalui pembentukan instrumen hukum dan kelembagaan HAM. Juga dapat melalui berbagai faktor yang berkaitan dengan upaya pencegahan HAM yang dilakukan individu maupun masyarakat dan negara. Negaralah yang memiliki tugas utama untuk melindungi warga negaranya termasuk hak- hak asasinya.

\section{KESIMPULAN}

Hak asasi manusia adalah hak-hak yang telah dipunyai seseorang sejak ia dalam kandungan dan merupakan pemberian dari Tuhan. Hak asasi manusia tidak pernah lepas dari kewajiban asasi manusia. Hak mengimplementasikan kewajiban, sebab hak hanya menjadi hak setelah kewajiban terpenuhi. Hak asasi manusia menjadi sarana utama untuk menjamin rasa solidaritas antara yang kuat dan yang lemah dalam masyarakat modern. Ada 3 hak asasi manusia yang paling fundamental (pokok), yaitu: Hak Hidup (life), Hak Kebebasan (liberty), Hak Memiliki (property).

Dalam Perjanjian Lama, hak asasi manusia bersumber pada pernyataan Allah terhadap manusia, pada tindakan Allah dalam sejarah manusia. Manusia diberikan kewenangan untuk mengatur dan menguasai ciptaan lainnya, baik dalam memberi nama maupun memanfaatkannya demi keberlanjutan hidupnya.

Dasar-dasar HAM adalah dari akar keagamaan. Manusia adalah gambar Allah atau dalam bahasa Paulus, human is divine original. Alkitab memberikan tempat yang sangat tinggi bagi martabat manusia, sehingga secara eksplisit ada perintah-perintah untuk menghormati martabat manusia. Hak asasi manusia bersumber pada pernyataan Allah terhadap manusia, pada tindakan Allah dalam sejarah manusia. Yesus tampil sebagai pembela HAM. Namun justru karena hal inilah, Ia dibenci dan dimusuhi. Yesus diadili dan akhirnya dihukum mati di kayu salib. Yesus, sosok pembela HAM telah menjadi korban pelanggaran HAM.

Pelanggrana HAM terhadap Yesus dilakukan oleh pemerintah yang berkuasa. Alkitab memberikan tempat yang sangat tinggi bagi martabat manusia, ada perintah untuk menghormati martabat manusia. Kisah Perempuan Samaria (Lukas 10:25-37), menekankan adanya penghargaan dan kewajiban terhadap hak hidup orang lain. Manusia mempunyai hak untuk berbicara dengan bebas dan untuk berbuat seturut hati nuraninya. Alkitab mengajarkan, setiap orang harus berbuat, berkata-kata seturut dengan hati nuraninya. Manusia mempunyai hati nurani yang murni baik terhadap Allah maupun terhadap sesama. 
Berkembangnya teknologi juga menciptakan cara baru bagi pelanggaran HAM. Maka dari itu dibutuhkan solusi dari permasalahan di atas. Dalam menangani kasus di atas pemerintah mengeluarkan Undang-Undang No. 11/2008 tentang Informasi dan transaksi Elektronik (ITE) yaitu UU yang mengatur tentang informasi serta transaksi elektronik, atau teknologi informasi secara umum. UU ini dibuat pemerintah karena semakin kesini pelanggaran semakin banyak bentuk dan tempatnya, UU tentang HAM yang telah ada dirasa belum cukup dalam menangani kasus HAM di era millenial ini. Maka dibentuklah UU ITE. Selain itu upaya untuk mencegah masalah ini juga dapat dilakukan oleh kita sebagai ndividu yang menggunakan sosial media agar lebih bijak dalam berpendapat dan peran orang tua khususnya dalam mengawasi anak-anaknya menggunakan sosial media agar tidak terjebak menjadi pelakaku pelangaran HAM.

\section{DAFTAR PUSTAKA}

Abineno J.L. Ch, Khotbah Di Bukit (Jakarta: BPK Gunung Mulia, 1996)

Banawiratma JB, Hak Asasi Manusia: Tantangan Bagi Agama (Yogyakarta: Kanisius, 1999)

Barnett Jake, Harta dan Hikmat-Pandangan Alkitab tentang Kekayaan (Bandung: Kalam Hidup, 1987)

Bonhoeffer Dietrich, Ethics (New York: MacMillan, 1975)

Borg J. Marcus, Jesus: Uncovering the Life, Teaching, and Relevance of a Religious Revolutionary (San Fransisco: Harper San Fransisco, 2006)

Davidson Scott, Hak Asasi Manusia (Jakarta: PT. Temprint, 1994)

Elwood Dooglas G., Human Rights: A Christian Perspective (Quezon City: New Day, 1990)

Heer de J.J., Tafsiran Alkitab Injil Matius (Jakarta: BPK Gunung Mulia, 1982)

Komisi Nasional Hak Asasi Manusia (ed), Hak Asasi Manusia dalam Perspektif Budaya Indonesia (Jakarta: PT. Gramedia Pustaka Utama, 1997)

Lempp Walter, Tafsran Alkitab Kejadian 5:1-12:3 (Jakarta: BPK Gunung Mulia, 1987)

Marsahall D. Christopher, Crowned Glory \& Honor (New Zealand: Pandora Press, 2002)

Sairin Weinata dan Pattiasina J.M, Hubungan Gereja dan Negara dan Hak Asasi Manusia (Jakarta: BPK Gunung Mulia, 1994)

Sobur Alex, Butir-Butir Mutiara Rumah Tangga (Yogyakarta: Kanisius, 1985)

Tribe Phyllis, Texts of Terror, Literary-Feminist Reading of Biblical Narratives (Philadelphia: Fortess Press, 1985)

Weissbrodt D, Human Rights: An Historical Perspective (London: Routledgr, 1988) 